\title{
Type-2 Astrocyte Development in Rat Brain Cultures Is Initiated by a CNTF-like Protein Produced by Type-1 Astrocytes
}

\author{
Laura E. Lillien,* Michael Sendtner, ${ }^{\dagger}$ \\ Hermann Rohrer, ${ }^{\dagger}$ Simon M. Hughes, ${ }^{\star \ddagger}$ \\ and Martin C. Raff* \\ * URC Developmental Neurobiology Program \\ Department of Biology \\ Medawar Building \\ University College London \\ London WC1E 6BT \\ $t$ Department of Neurochemistry \\ Nax-Planck-Institute for Psychiatry \\ A:n Klopferspitz 18a \\ D-8033 Martinsried \\ Ft'deral Republic of Germany
}

\section{Summary}

0-2A progenitor cells are bipotential glial precursors that give rise to both oligodendrocytes and type-2 astrocytes on a precise schedule in the rat CNS. Studies in culture suggest that oligodendrocyte differentiation occurs constitutively, while type-2 astrocyte differentiation requires an exogenous inducer such as fetal calf serum. Here we describe a rat brain cell culture system in which type-2 astrocytes develop on schedule in the absence of exogenous inducers. Coincident with type2-astrocyte development, the cultures produce an $\sim 20$ kd type-2-astrocyte-inducing factor(s). Purified cultures of type-1 astrocytes can produce a similar factor(s). Under conditions where they produce type-2-astrocyte-inducing factor(s), both brain and type-1 astrocyte cultures produce a factor(s) with ciliary neurotrophic (CNTF)-like activity. Purified CNTF, like the inducers from brain and type-1 astrocyte cultures, prematurely induces type-2 astrocyte differentiation in brain cultures. These findings suggest that type- 2 astrocyte development is initiated by a CNTF-like protein produced by type-1 astrocytes.

\section{Introduction}

We have been studying the role of cell-cell interactions in regulating the development of macroglial cells in the rat CNS. There are three major classes of CNS macroglial cells, and they differentiate on a precise schedule in vivo: type-1 astrocytes develop first, beginning at em. bryonic day 15-16 (E15-E16); oligodendrocytes develop $n \in x t$, beginning around birth; and finally type- 2 astrocytes develop, beginning in the second postnatal week (Abney et al., 1981; Miller et al., 1985; Williams et al., 1985). Using antibodies to identify and manipulate glial precursor cells and their differentiated progeny, we have shown that oligodendrocytes and type-2 astrocytes develop in vitro from a common precursor, termed the

* Fresent address: Department of Pharmacology, Stanford Universit. Medical School Stanford, California 94305.
O-2A progenitor cell, while type-1 astrocytes develop from a different precursor (Raff et al., 1983a, 1983b, 1984).

In vitro studies suggest that the timing and direction of O-2A progenitor cell development are greatly influenced by environmental factors. In cultures of perinatal rat optic nerve cells, for example, which contain al three types of macroglial cells and their precursors but no neurons, the timing of $\mathrm{O}-2 \mathrm{~A}$ progenitor cell differentiation into oligodendrocytes has been shown to be regulated by a growth factor secreted by type- 1 astrocytes (Noble and Murray, 1984; Raff et al., 1985). The growth factor, recently identified as platelet derived growth factor (PDGF) (Richardson et al., 1988), stimulates the proliferation of O-2A progenitor cells and prevents their pre. mature differentiation into oligodendrocytes. Even in the continuous presence of PDGF, however, progenitor cells eventually stop dividing and differentiate into oligoden. drocytes, a sequence precisely timed by a mechanism that appears to be intrinsic to the progenitor cell (Raff et al., 1988). Oligodendrocyte differentiation occurs in optic nerve cultures grown in defined, serum-free medium (Raff et al., 1983b), even in the absence of growth factors reported to promote oligodendrocyte differentiation, such as insulin and IGF-1 (MCMorris et al., 1986; DuboisDalcq, 1987). Type-2 astrocytes, on the other hand, do not develop in optic nerve cultures grown in defined medium; their differentiation requires an exogenous inducer such as fetal calf serum (FCS) (Raff et al., 1985). These observations suggest that oligodendrocyte differentiation occurs constitutively, whereas type-2 astrocyte differentiation is induced.

To analyze the mechanism by which type- 2 astrocyte differentiation is normally induced, we have attempted to reconstitute the normal induction process in vitro. We demonstrate the following: First; type-2 astrocytes can develop on schedule in cultures of perinatal rat brain cells grown without FCS. Second, starting at the time type-2 astrocytes first appear, the cultures produce an $\sim 20 \mathrm{kd}$ protein that induces $\mathrm{O}-2 \mathrm{~A}$ progenitor cells to begin to develop into type-2 astrocytes. Third, O-2A progenitor cells can respond to this inducing factor at least $T$ week earlier than it would normally appear in the culture medium, suggesting that the production and release of the inducing factor, not the onset of progenitor cell responsiveness to it, are responsible for timing type- 2 as. trocyte development. Fourth, purified type-1 astrocytes release a similar inducing protein within $24 \mathrm{hr}$ of mechanical injury, suggesting that they may be the source of this factor in brain cell cultures. Fifth, under conditions where they produce factors with type-2-astrocyte-inducing activity, both brain and type-1 astrocyte cultures produce factors that mimic the effect of ciliary neurotrophic factor (CNTF) in supporting the survival of ciliary neurons in vitro. Finally, purified CNTF prematurely induces type- 2 astrocyte differentiation in brain cultures. These findings suggest that the timing of type-2 astrocyte differentiation depends on a CNTF-like protein produced 


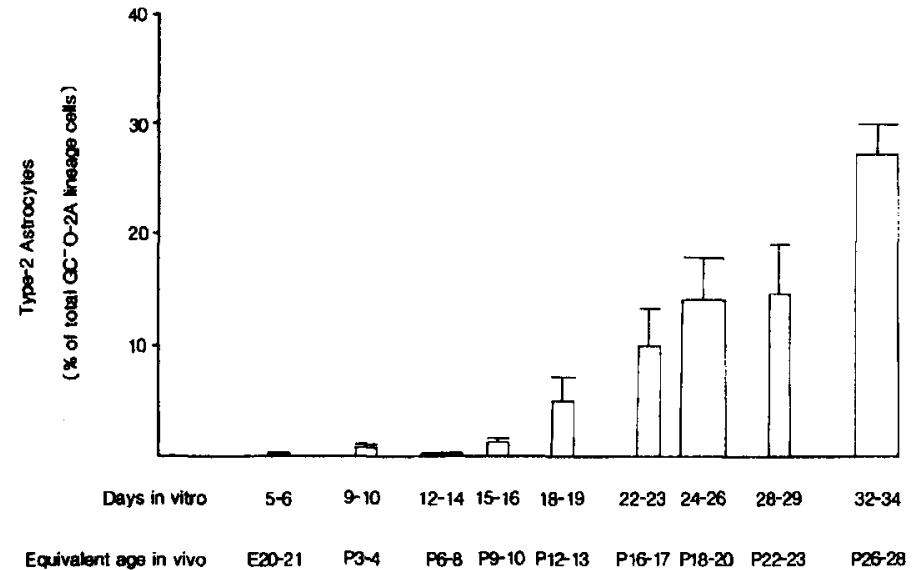

Figure 1. Time Course of Type-2 Astrocyte Development in Cultures of E15 Brain Cells Type- 2 astrocytes were identified as $\mathrm{A}_{2} \mathrm{BS}^{+}$. GFAP+, $\mathrm{GC}^{-}$process-bearing cells. $\mathrm{A}^{-} \mathrm{B}^{+}$ $\mathrm{GC}^{-} \mathrm{O}-2 \mathrm{~A}$ lineage cells could readily be distinguished from neurons that were also $\mathrm{A}^{2} \mathrm{~B}^{+}, \mathrm{GC}^{-}$process-bearing cells by their distribution and intensity of $\mathrm{A} 2 \mathrm{~B} 5$ labeling: $O-2 A$ lineage cells tended to grow in clusters (probably clones) near the periphery of the cultures, and they stained more intensely with A2B5 antibody than did neurons, which tended to form tight aggregates. These as signments were confirmed in some experiments by staining with the RT97 anti-neuro filament monoclonal antibody. The cultures were grown in defined medium, with or without $0.5 \% \mathrm{FCS}$; the addition of $0.5 \% \mathrm{FCS}$ did not alter the results. The results are expressed as the mean \pm SEM of cultures from two to four different platings. by type-1 astrocytes. The CNTF-like inducing protein apparently only initiates type- 2 astrocyte differentiation; however, an additional factor(s) seems to be needed to complete the process.

\section{Results}

Type-2 Astrocytes Develop on Time in Brain Cell Cultures in the Absence of FCS

In a previous study, type- 2 astrocytes were found to develop on schedule in cultures of early embryonic brain cells grown in $10 \%$ FCS but not in serum-free or low serum $(0.5 \%)$ medium (Williams et al., 1985). In that study, type- 2 astrocyte development could only be assessed in cell suspensions prepared from the brain cultures, as the cultures were too dense to permit accurate identification of these cells in the cultures themselves. We have circumvented the density problem by growing brain cells at low density; this was possible only when the low density cultures were sustained by coculture with cultures containing 20-fold more of the same cells.

When brain cells from $\mathrm{E} 15$ rats were grown in serumfree defined medium (or defined medium containing $0.5 \%$ FCS) using this coculture system, oligodendrocytes, identified by the binding of anti-galactocerebroside (anti-GC) antibody (Raff et al., 1978), first appeared after about a week in vitro, as previously reported (Abney et al., 1981; Williams et al., 1985). This is equivalent to the time of birth. Moreover, type-2 astrocytes also developed in these cultures and could first be seen in significant numbers after 15-18 days (Figure 1), which is the same time they begin to develop in substantial numbers in cultures grown with $10 \% \mathrm{FCS}$ and is equivalent to the time they begin to develop in vivo (Williams et al., 1985) Type- 2 astrocytes (Raff et al., 1983a) were identified as process-bearing cells that were stained on their surface with the A2B5 monoclonal antibody (Eisenbarth et al., 1979) (but not with the anti-GC antibody) and intracellularly with antibodies against glial fibrillary acidic protein
(CFAP), an astrocyte-specific marker in the rat CNS (Bignami et al., 1972). The type- 2 astrocytes developed in clusters, which could be seen most easily at the periphery of the cultures (Figure 2).

Brain Cultures Produce an 20 kd Type-2-AstrocyteInducing Factor at the Time Type-2 Astrocytes Develop The development of type-2 astrocytes in the absence of FCS in brain cultures suggested that these cultures might produce an endogenous type-2-astrocyte-inducing factor(s). As shown in Figure 3, beginning at the equivalent of P10-P12 (i.e., after 16-18 days in vitro), cultures of E15 brain released into the medium a diffusible factor(s) that could induce $\mathrm{O}-2 \mathrm{~A}$ progenitor cells in neonatal optic nerve cultures to express GFAP. (Type-2-astrocyte-inducing activity was assayed in optic nerve cultures rather than in brain cultures because $\mathrm{O}-2 \mathrm{~A}$ lineage cells are more prevalent and more easily identified in neuron-free optic nerve cultures.) The timing of the appearance of this factor(s) thus coincided with the development of type- 2 astrocytes in the embryonic brain cultures. The timing was not simply a reflection of time in culture since the diffusible factor(s) appeared after only 6-9 days in cultures prepared from newborn rather than $\mathrm{E} 15$ brain (Figure 3 ). Nor was the timing a reflection of a critical cell density since type-2-astrocyte-inducing activity did not appear earlier in cultures plated at a cell density 3 -fold higher than normal (data not shown). Cultures of brain cells continued to release type-2-astrocyte-inducing factor(s) for at least 8 weeks (data not shown).

The time of appearance of the type-2-astrocyte-inducing activity in the culture medium apparently reflected an increase in its production, since extracts of cultures of $\mathrm{E} 15$ brain made after $8-12$ days in vitro had relatively little inducing activity whereas extracts of older cultures (25-34 days in vitro) had at least 50-fold more activity (Figure 4). The inducing activity in conditioned medium was usually present at limiting concentration: a dilution of even 1:1 resulted in a partial or complete loss of activ- 

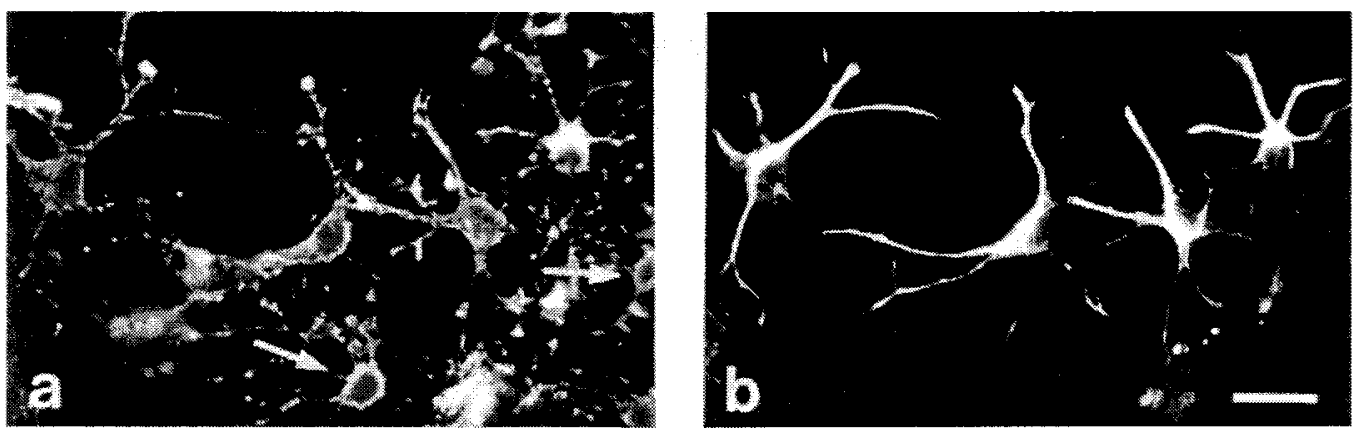

Figure 2. Type-2 Astrocytes in Cultures of E15 Brain Cells after 24 Days In Vitro in Serum-Free Defined Medium

Th e cultures were stained with A2B5 antibody (followed by G anti-MlgRd) and, after fixation in acid-alcohol, with anti-GFAP antiserum (folloived by Sh anti-RIgFI). They were photographed with rhodamine (a) and fluorescein (b) optics. There are four type-2 astrocytes (A2B5 ${ }^{+}$, $\left.\mathrm{Gl}: \mathrm{AP}^{+}\right)$and two $\mathrm{O}-2 \mathrm{~A}$ progenitor cells $\left(\mathrm{A} 2 \mathrm{B5}^{+}, \mathrm{CFAP}-\right.$ ) (arrows) in the field. Bar, $25 \mu \mathrm{m}$.

it $\%$ Extracts of older cultures contained at least 50 -fold more inducing activity per $\mathrm{ml}$ than conditioned medium (CM) from the same cultures. Even high concentrations of extracts, however, induced only $20 \%-35 \%$ of the C.2A progenitor cells in optic nerve cultures to express GFAP, which was the same proportion induced by $C M$.

Treatment of $\mathrm{CM}$ or extracts of older brain cultures with trypsin completely destroyed the GFAP-inducing activity (data not shown), suggesting that the inducing factor(s) is a protein(s). To determine the approximate size of the protein(s), extracts of older cultures (E15 + 34 days in vitro) were fractionated by fast protein liquid chromatography (FPLC) on a Superose 12 gel filtration column. Type-2-astrocyte-inducing activity was found in a single peak centered at about $20 \mathrm{kd}$ (Figure 5a). No in- ducing activity could be detected in any fractions prepared from extracts of younger cultures $(\mathrm{E} 15+12$ days in vitro), suggesting that the absence of inducing activity was not due to the presence of a smaller or larger inhibitory molecule.

\section{Cultures of Type-1 Astrocytes Release an $\sim 20$ kd Type-2-Astrocyte-Inducing Protein When They Are Injured}

To identify the cellular source of the type-2-astrocyteinducing factor(s), we tested media conditioned by several types of cultures, including cultures of newborn retina (which contains neurons, Müller cells, and some type-1 astrocytes, but no O-2A lineage cells) (ffrenchConstant et al., 1988) and cultures enriched for oligoden-

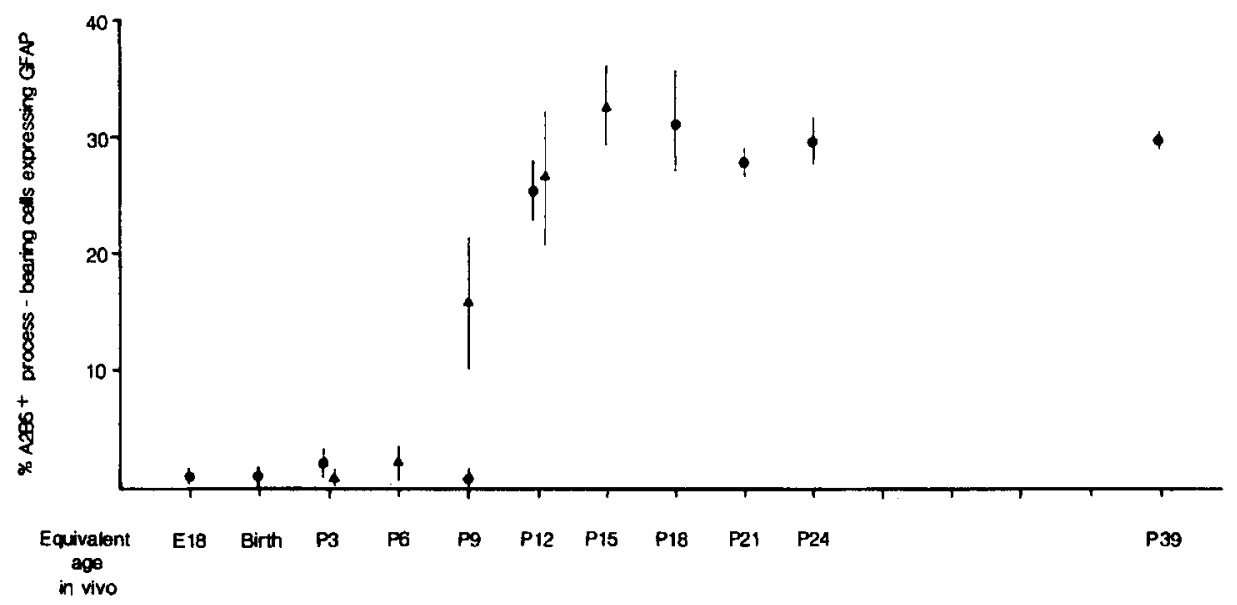

Figure 3. The Time Course of Appearance of Type-2-Astrocyte-Inducing Activity in Conditioned Medium (CM) from E15 and Newborn Brain C.ll Cultures

$\mathrm{CM}$ was collected at 3 day intervals and tested an cultures of newborn optic nerve cells for type-2-astrocyte-inducing activity. The optic nerve cultures were grown in undiluted $\mathrm{CM}$ for 1 day and then fixed and stained with A2B5 and anti-GFAP antibodies as in Figure 2. The proportion of $\mathrm{A} 2 \mathrm{~B} 5^{+}$process-bearing cells expressing GFAP was determined. The E15 brain cultures (-) were grown in defined medium, with or with out $0.5 \%$ FCS, while the newborn brain cultures $(\mathbf{A})$ were grown in defined medium containing $0.5 \%$ FCS. The presence of $0.5 \%$ FCS did nct alter the results. At least $100{\mathrm{~A} 2 \mathrm{~B}^{+}}^{+}$process-bearing cells were counted per coverslip, and the results are expressed as the mean \pm SEM of three to four coverslips. 


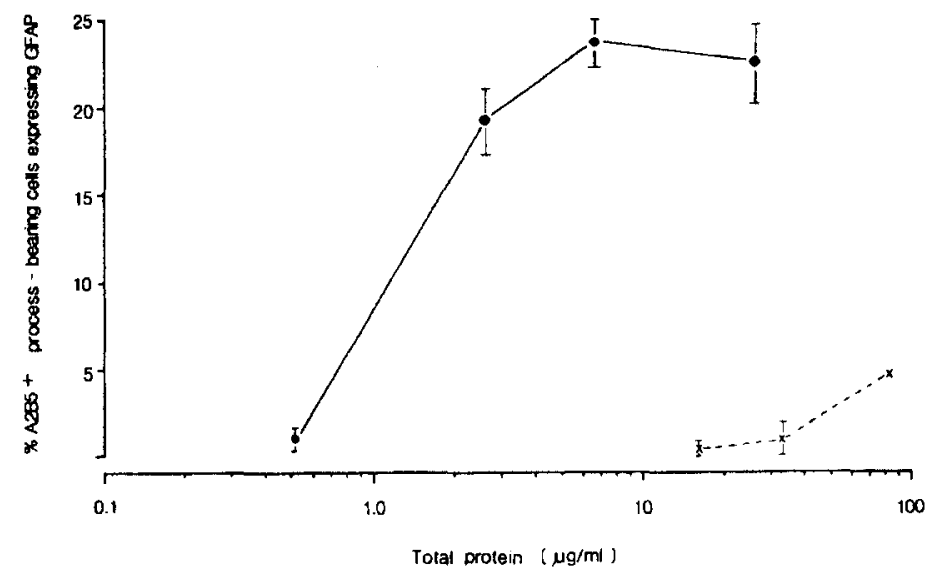

a

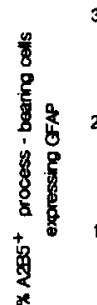

30
20
10

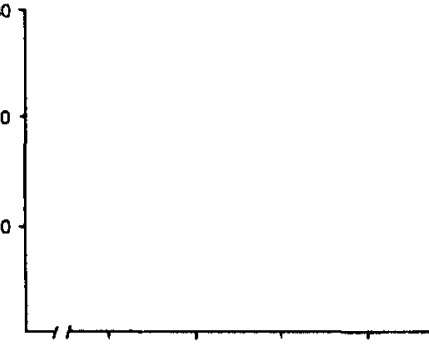

12 $\stackrel{6064}{19} \quad \stackrel{20}{1} \quad \stackrel{12}{1}$

14

Elution volume $(\mathrm{ml})$

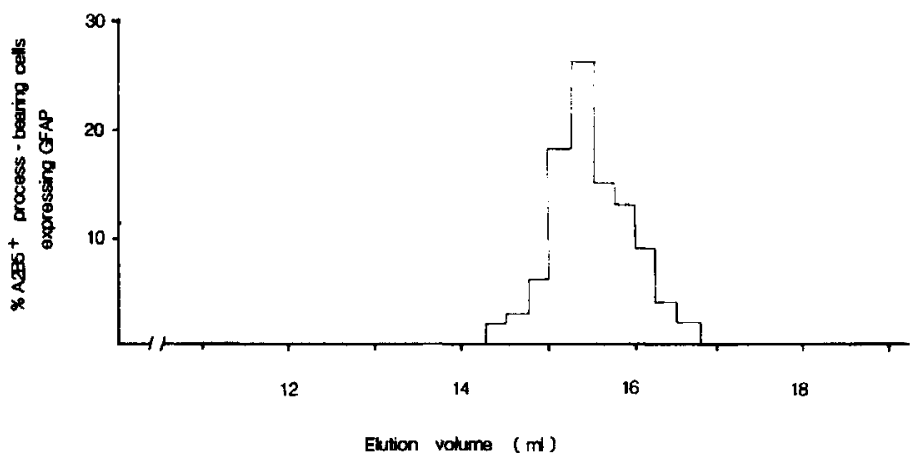

Figure 4. Type-2-Astrocyte-Inducing Activity in Extracts of Young and Old Brain Cell Cul tures

Extracts of E 15 brain cell cultures after 8 days $(x)$ or 34 days ( ) in vitro were assayed using cultures of newborn optic nerve cells as in Figure 3. Results are expressed as the mean \pm SEM of two $(E 15+8)$ or three $(E 15+34)$ cultures. Similar results were obtained with extracts of several other young and old brain cultures.

Figure 5. FPLC Gel Filtration Fractionation of Extracts of E15 Brain Cell Cultures after 34 Days In Vitro and CM from Injured Type-1 As. trocyte Cultures

(a) Brain culture extracts $(100 \mu \mathrm{l}$; approximately $250 \mu \mathrm{g}$ total protein) and (b) concentrated astrocyte CM $(100 \mu \mid)$ were separated into $0.25 \mathrm{ml}$ fractions, diluted 1:10, sterilized by filtration, and assayed for type-2-astrocyteinducing activity using newborn optic nerve cultures as in Figure 3. Arrows indicate the positions of size markers: BSA $(66 \mathrm{kd})$, ovalbumin $(45 \mathrm{kd}$ ), soybean trypsin inhibitor $\{20$ $\mathrm{kd})$, and cytochrome $\mathrm{C}(12 \mathrm{kd})$.

\section{b}

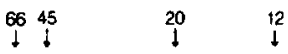

drocytes, type- 1 astrocytes, or meningeal cells. As shown in Table 1 , none of these cultures released type-2. astrocyte-inducing factor(s). Following mechanical injury (scratching the monolayer or passaging the cells), how- ever, type-1 astrocyte cultures, but none of the other types of cultures, released a factor(s) with type-2-astrocyteinducing activity. Like the inducing activity produced by older brain cell cultures, medium conditioned by injured 


\begin{tabular}{|c|c|c|}
\hline$C M$ from Cultures & & $\begin{array}{l}\% \text { of } A 2 \mathrm{BS}^{+} \\
\text {Process-Bearing } \\
\text { Cells Expressing GFAP }\end{array}$ \\
\hline T)pe-1 astrocytes & $\begin{array}{l}\text { - uninjured } \\
\text { - injured }\end{array}$ & $\begin{array}{r}0.5 \pm 0.1 \\
27.7 \pm 2.7\end{array}$ \\
\hline Moningeal cells & $\begin{array}{l}\text { - uninjured } \\
\text { - injured }\end{array}$ & $\begin{array}{l}0.1 \pm 0.05 \\
0.07 \pm 0.03\end{array}$ \\
\hline Retina & $\begin{array}{l}\text { - uninjured } \\
\text { - injured }\end{array}$ & $\begin{array}{l}0.03 \pm 0.03 \\
0\end{array}$ \\
\hline ()igodendrocyles & $\begin{array}{l}\text { - uninjured } \\
\text {-injured }\end{array}$ & $\begin{array}{l}0.6 \pm 0.2 \\
0.3 \pm 0.3\end{array}$ \\
\hline
\end{tabular}

$\bar{N}$ :swborn optic nerve cells were either cultured for 1 day in $\mathrm{CM}$ frum type-1 astrocytes or meningeal cells, or cocultured on separate cc verslips with these cells, retinal cells, or optic nerve oligodendrocytes. The induction of GFAP was assayed as in Figure 3 . The results are expressed as the mean \pm SEM of at least three coverslips.

ty pe-1 astrocytes, and extracts made from such injured cells, induced only $20 \%-35 \%$ of optic nerve O-2A progenitor cells to express GFAP. The inducing factors produced by brain and injured type-1 astrocyte cultures were not additive or synergistic when applied together at optimal concentrations (data not shown).

We concentrated medium conditioned by injured t) pe-1 astrocyte cultures and fractionated it by FPLC on a Superose 12 gel filtration column. As shown in Figure 50, the type-2-astrocyte-inducing activity was found in a single broad peak centered at approximately $20 \mathrm{kd}$. Extracts prepared from these cultures contained a similar single peak of inducing activity (data not shown).

\section{O-2A Progenitor Cells Are Prematurely Responsive} ti) Type-2-Astrocyte-Inducing factors

in the experiments described above, CM and culture ex tracts were tested for type-2-astrocyte-inducing activity using O-2A progenitor cells in cultures of newborn optic rerve. The results indicated that these progenitor cells can respond to the type-2-astrocyte inducer(s) at least 1 week before type- 2 astrocytes normally begin to develop. To determine whether O-2A progenitor cells in $t$ rain cultures, which contain neurons, are also prema$t$ srely responsive to type-2-astrocyte-inducing factors, we exposed cultures of newborn brain cells to inducing factor(s) from either old brain cultures or injured type-1 astrocyte cultures. In both cases many O-2A progenitor cells were prematurely induced to express GFAP within $\therefore 4 \mathrm{hr}$ (Table 2).

Brain and Astrocyte Cultures Produce a Factor(s) with CNTF-like Activity, and Pure CNIF Induces Type-2 Astrocyte Differentiation in Brain Cultures

1. has been reported that type-1 astrocyte cultures relase a number of growth-promoting factors following rechanical injury (Rudge et al., 1985). One of these factors is thought to be CNTF (Manthorpe et al., 1986a), which is similar in size (Barbin et al., 1984; Carnow et il., 1985; Manthorpe et al., 1986b) to the type-2-astro-

\begin{tabular}{|c|c|}
\hline Additive & $\begin{array}{l}\text { Total Number of } \mathrm{A}^{2} \mathrm{B4}^{+} \text {, } \\
\text { GFAP+ Process-Bearing } \\
\text { Cells per Culture }\end{array}$ \\
\hline None & $6.0 \pm 2.2$ \\
\hline $\begin{array}{l}\text { Extract of E15 brain culture } \\
\text { after } 25 \text { days in vitro }(42 \mu \mathrm{g} / \mathrm{ml})\end{array}$ & $189.2 \pm 28.3$ \\
\hline $\begin{array}{l}\text { Medium condition by injured } \\
\text { type- } 1 \text { astrocyte culture } \\
\text { (diluted } 1: 50 \text { ) }\end{array}$ & $211.5 \pm 3.7$ \\
\hline CNTF $(3 \mathrm{ng} / \mathrm{ml})$ & $255.7 \pm 17.9$ \\
\hline $\begin{array}{l}\text { CNTF }(3 \mathrm{ng} / \mathrm{ml}) \\
+ \\
\text { Extract of E15 brain culture } \\
\text { after } 25 \text { days in vitro }(42 \mu \mathrm{g} / \mathrm{ml}) \\
\quad+ \\
\text { Medium conditioned by injured } \\
\text { type-1 astrocyte culture } \\
\text { (diluted } 1: 50)\end{array}$ & $220.3 \pm 23.9$ \\
\hline
\end{tabular}

Newborn brain cells $(20,000)$ were cultured on poly-o-lysine-coated coverslips in the additives indicated for 7 day and then stained with A2B5 and anti-GFAP antibodies as described in Figure?. The results are expressed as the mean \pm SEM of four coverslips.

cyte-inducing factor(s) produced by cultures of brain cells and injured type-1 astrocytes. Ion-exchange chromatography of medium conditioned by injured type-1 astrocytes and extracts of brain cultures indicated that, like CNTF (Barbin et al., 1984; Manthorpe et al., 1986b), these inducing factors were acidic (unpublished observations). When pure CNTF was added to cultures of newborn brain cells, it mimicked (but did not increase) the effect of type-2-astrocyte-inducing factors from brain and type-1 astrocyte cultures, inducing the premature expression of GFAP in a substantial number of $\mathrm{A}_{2} \mathrm{~B}^{+}$ process-bearing cells (Table 2; Figure 6).

If the type-2-astrocyte-inducing factor(s) produced by injured type-1 astrocytes is CNTF, then extracts of, or medium conditioned by, such cells should also support the survival of ciliary neurons in vitro, as previously reported (Rudge et al., 1985). This was found to be the case, and the dose-response curves for type- 2 astrocyte induction and ciliary neuron survival were very similar (data not shown). Moreover, extracts of old brain cultures ( $\mathrm{E} 15+25-34$ days in vitro) supported the survival of ciliary neurons in culture, while extracts of young brain cultures ( $E 15+8-12$ days in vitro), which had little type2-astrocyte-inducing activity, had little CNTF activity (Figure 7$)$; in both cases, the dose-response curves for type2 astrocyte induction and neuronal survival were similar (compare Figure 4 and Figure 7 ).

\section{More than One Factor Seems to Be Required for} Type-2 Astrocyte Development

When type-2-astrocyte-inducing factor(s) from cultures of brain cells or injured type-1 astrocytes was added to newborn optic nerve cell cultures, $\mathrm{A}^{2} \mathrm{B5}^{+}, \mathrm{GFAP}^{+}$pro- 

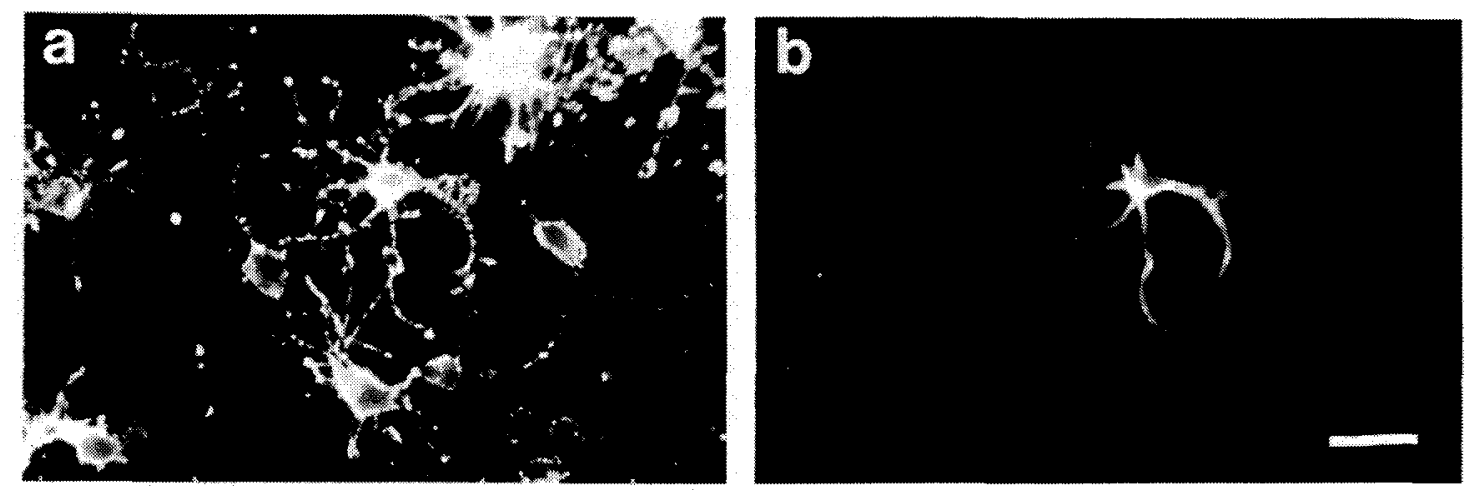

Figure 6. Premature Induction of a Type-2 Astrocyte by CNTF in a Culture of Newborn Brain Cells

The cells were cultured with CNTF for 1 day as described in Table 2, stained with A2B5 (a) and anti-GFAP (b) antibodies, and photographed with rhodamine and fluorescein optics. Bar, $25 \mu \mathrm{m}$.

cess-bearing cells, characteristic of type-2 astrocytes, were seen within $24 \mathrm{hr}$; after 3 days, however, few if any such cells remained (data not shown). The same results were obtained when the inducing factor(s) was added daily or when the optic nerve cells were cocultured with injured type-1 astrocyte cultures to ensure continuous exposure to the inducer. Preliminary experiments suggest that the cells in optic nerve cultures which are induced to express GFAP in response to these inducers subsequently develop into oligodendrocytes (L. E. L. and $M$. C. R., unpublished data). It seems that this inducing factor(s) can initiate type-2 astrocyte differentiation, but other signals, perhaps mediated by cell-cell contact, are apparently required to induce stable expression of the type- 2 astrocyte phenotype.

\section{Discussion}

In this report we have provided evidence that the differentiation of type-2 astrocytes in brain cultures depends on the production of an endogenous inducing factor similar to CNTF. In this culture system the population of
O-2A progenitor cells differentiates on the same schedule in vitro as in vivo, giving rise initially to oligodendrocytes and then to type- 2 astrocytes. The advantage of this culture system over a similar one described previously (Williams et al., 1985) is that here type-2 astrocytes could be observed to develop in the absence of FCS, which itself induces type- 2 astrocyte differentiation in cultures of optic nerve cells (Raff et al., 1983b). It was this feature that enabled us to demonstrate and characterize the type-2-astrocyte-inducing factor(s).

\section{Type-2-Astrocyte-Inducing Factors Are \\ CNTF-like Proteins}

Hughes and Raff (1987) recently described a 20-25 kd protein in extracts of 3-4 week old rat optic nerve that induces $\mathrm{O}-2 \mathrm{~A}$ progenitor cells in cultures of newborn optic nerve to express GFAP. Several lines of evidence suggest that the type-2-astrocyte-inducing factor(s) produced by brain cell cultures at the time type- 2 astrocytes begin to develop is the same or very similar to the factor in optic nerve extracts. Both factors elute in the same position when fractionated by FPLC on a Superose 12 gel

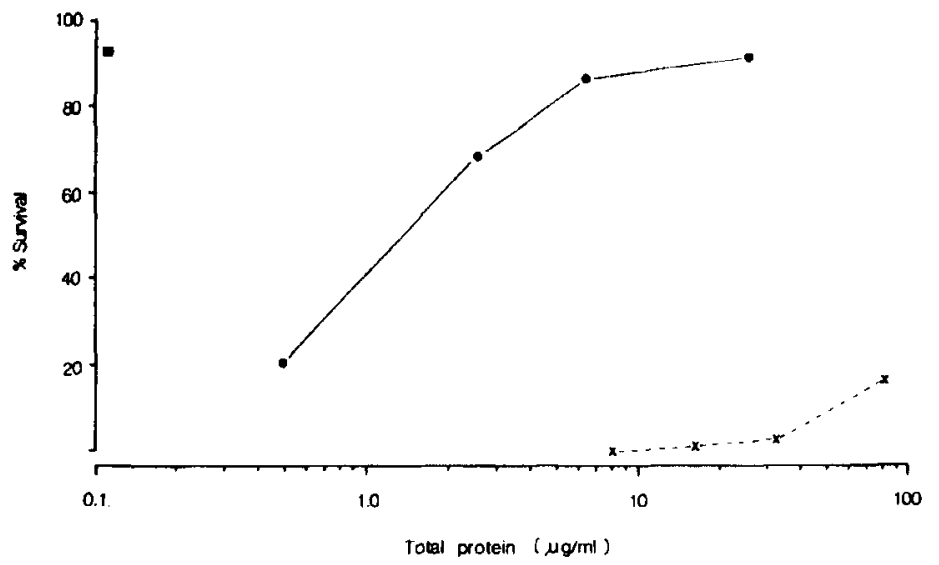

Figure 7. CNTF activity in Extracts of Old and Young Brain Cell Cultures

Old cultures (O) consisted of E15 + 34 days in vitro cells; young cultures $(x)$ consisted of $\mathrm{E} 15+\mathbf{8}$ days in vitro cells. The same extracts that were assayed for type-2-astrocyteinducing activity in Figure 4 were tested for their ability to support the survival of $E B$ chick ciliary neurons for 1 day in culture. The results are expressed as the proportion of neurons present after $24 \mathrm{hr}$ compared with the number counted $2 \mathrm{hr}$ after plating. CNTF $(5 \mathrm{ng} / \mathrm{ml})$ was used as a positive control (n) 
filtration column (this study; Hughes and Raff, 1987). Both factors induce only $20 \%-35 \%$ of the $0-2 \mathrm{~A}$ progenitc: cells in newborn optic nerve cultures to express GFAP (this study; Hughes and Raff, 1987), and their effects are not additive or synergistic (unpublished data); ir both cases the induction of GFAP is transient.

The results presented here and elsewhere (S. M. H., L. E. L., M. C. R., H. R., and M. S., submitted) suggest th at the type-2-astrocyte-inducing protein(s) found in cultures of brain cells and in extracts of optic nerve is related, if not identical, to CNTF. CNTF was originally $\mathrm{d}$ scovered as an activity in heart cell-conditioned me$d$ um that promotes the survival of chick ciliary ganglion $n$ ?urons in vitro (Helfand et al., 1976). Subsequently characterized as a $20-25 \mathrm{kd}$ acidic protein (Barbin et al., 1'384; Carnow et al., 1985; Manthorpe et al., 1986b) that promotes the in vitro survival of several types of periphe al neurons, it has been found in a variety of tissues (E bendal, 1987), including brain (Carnow et al., 1985; Nieto-Sampedro et al., 1983), and has been purified from C rick eye (Barbin et al., 1984) and rat sciatic nerve (Manthorpe et al., 1986b). At least three lines of evidence suggest that the type-2-astrocyte-inducing protein(s) is the sitme or similar to CNTF. First, it has similar chemical poperties to CNTF. Second, CNTF purified from rat sciatic nerve is a potent inducer of type-2 astrocyte diffe-rentiation in cultures of optic nerve cells $(S . M$. H. et a ., submitted) and brain cells (this study). Third, extracts of brain cultures (this study) and optic nerve (S. M. H. e. al., submitted) support ciliary neuron survival in vitro a concentrations that correlate well with their ability to iriduce type-2 astrocyte differentiation.

The Timing of Type-2 Astrocyte Development Depends on the Production and/or Secretion of the CNTF-like Protein(s)

The timing of type- 2 astrocyte development both in vitro and in vivo appears to depend only on the timed production and release of the CNTF-like protein(s) and not on the onset of O-2A progenitor cell responsiveness to it. In cultures of embryonic brain cells, both the large iricrease in production and the release of type-2-astrocrte-inducing factor(s) coincide with the development of type-2-astrocytes. Similarly, the concentration of inducing factor in extracts of optic nerve increases 20- to 5]-fold between the first postnatal week, before type-2 a itrocyte development has begun, and the third postnat. I week, when their development is well under way (isiller et al., 1985; Hughes and Raff, 1987). The ability of extracts of brain cultures (this study) and optic nerve ( $\because$. M. H. et al., submitted) to support ciliary neuron sur$\checkmark$ val shows a similar developmental time course. By contıast, O-2A progenitor cells in cultures of brain (this study) a submitted) are responsive to the type-2-astrocyte-inducing factor(s) at least 1 week before type-2-astrocyte de$v$ alopment normally begins.

This timing mechanism differs from some other de$v$ sloping systems in which the regulation of timing has been studied. For example, Davies et al. (1987) have studied the timing of both NGF production and responsiveness to NGF during the development of sensory innervation to mouse whisker pads. In this case, the production of NGF and the responsiveness of sensory neurons to NGF are similarly timed, and responsiveness to NGF is not induced prematurely by exposure to NGF in vitro.

In cultures of brain cells, large scale production of type-2 astrocytes began at the equivalent of P10-P12. Not all of the O-2A progenitor cells in the cultures, however, differentiated into type- 2 astrocytes at this time, despite the presence of a diffusible type-2-astrocyteinducing factor(s) in the culture medium. Similarly, not all $\mathrm{O}-2 \mathrm{~A}$ progenitor cells in cultures of newborn optic nerve respond to the type-2-astrocyte-inducing factor(s), and no obvious difference distinguishes the $20 \%-35 \%$ of the cells that respond from those that do not. Preliminary experiments (L. E. L. and M. C. R., unpublished data) suggest that the timing of $\mathrm{O}-2 \mathrm{~A}$ progenitor cell responsiveness to the inducing factor(s) may depend on the same intrinsic timing mechanism that controls oligodendrocyte differentiation (Raff et al., 1985: Temple and Raff, 1986); whether a progenitor cell becomes a type-2 astrocyte or an oligodendrocyte when "time" is reached would then depend on whether or not a sufficient concentration of inducer protein is available.

\section{Type-1 Astrocytes in Culture Can Produce a CNTF-like Protein}

Which cells produce the type-2-astrocyte-inducing factor(s)? We found that cultures of purified type-1 astrocytes produced such a factor(s) when the cells were mechanically injured. The factor(s) was around $20 \mathrm{kd}$ and was indistinguishable from the tactor(s) derived from brain cultures or optic nerve in its ability to initiate type2 astrocyte differentiation. Cultures of retinal cells, meningeal cells, or optic nerve oligodendrocytes, by contrast, did not produce such a factor(s) when injured. A CNTFlike molecule has been previously shown to be produced by cultures of purified (type-1) astrocytes following mechanical injury (Rudge et al., 1985). These findings suggest that type-1 astrocytes may be the source of the CNTFlike factor(s) that initiates type- 2 astrocyte development.

In the absence of injury, the production and/or release of this factor(s) by type-1 astrocytes might require their interaction with another type of cell. In preliminary experiments we have studied the development of type-2 astrocytes in PDGF-containing, serum-free cultures of optic nerve cells, which were enriched for both $\mathrm{O}-2 \mathrm{~A}$ progenitor cells and oligodendrocytes but contained few type-1 astrocytes. Very few type-2 astrocytes develop under these conditions unless the cultures are combined with established cultures enriched for type-1 astrocytes (L. E. L. and M. C. R., unpublished data). This finding suggests that, even in the absence of injury, type-1 astrocytes may be required for the development oi type-2 astrocytes and that the production and/or rele'ase of the CNTF-like protein may require an interaction between type- 7 astrocytes, O-2A progenitor cells, and/or oligodendrocytes. 


\section{Other Signals May Be Required to Generate Stable Type-2 Astrocytes}

The CNTF-like proteins(s) produced by brain and astrocyte cultures and found in optic nerve extracts is apparently able to initiate type-2 astrocyte differentiation but is not able to drive the process to completion. Even when optic nerve cultures are exposed to it continuously, the factor(s) induces O-2A progenitor cells to express GFAP only transiently. The transient nature of the type- 2 astrocytes induced by this factor in optic nerve cultures does not reflect the inability of optic nerve $\mathrm{O}-2 \mathrm{~A}$ progenitor cells to develop into stable type-2 astrocytes in culture in the absence of FCS. We have recently found that stable type-2 astrocytes can develop in serum-free cultures of newborn optic nerve cells grown with PDCF (although PDGF itself neither induces nor stabilizes the development of type-2 astrocytes) (L. E. L. and M. C. R., unpublished data). Apparently other signals in addition to the CNTF-like protein(s) are required to generate a stable type-2 astrocyte.

Our results provide strong support for the hypothesis that type- 2 astrocyte differentiation is initiated by a CNTFlike protein that is produced relatively late in development. They also raise a number of questions. If type- 1 astrocytes are the normal source of the CNTF-like protein that initiates type- 2 astrocyte development, what regulates the timing of the protein's production? What determines whether an individual O-2A progenitor cell responds to this inducer? What is the nature and the cellular source(s) of the additional signals apparently required to stabilize the type- 2 astrocyte phenotype and how is the production of these signals controlled? The ability to reconstitute in vitro the control mechanisms responsible for timing type-2 astrocyte development is an important step toward answering these and other questions con cerning the regulation of O-2A progenitor cell differentiation.

Experimental Procedures

Animals

Timed pregnant Sprague-Dawley rats were obtained from the breed ing colony of the Imperial Cancer Research Fund. The age of em bryos was confirmed by crown-rump length (Angulo $Y$ Gonzales, 1932) and paw morphology (Long and Burlingame, 1938). Newborn rats used for brain and optic nerve cultures were less than 24 hr old.

Materials

FCS (Myoclone) was purchased from GIBCO. All other tissue culture reagents and molecular weight markers were purchased from Sigma. Plastic-ware was purchased from Falcon, while fluorescent conjugates were purchased from Wellcome (sheep anti-rabbit Igfluorescein is Sh anti-Rlg-Fl), Cappel (goat anti-mouse lg-rhodamine is $\mathrm{G}$ anti-Mig-Rd), and Nordic (goat anti-mouse $\operatorname{lgC} 3$-fluorescein is $\mathrm{G}$ anti-MigG.3-FI)

\section{Cell Cultures}

\section{Embryonic Brain}

Brains from $\mathrm{E} 15$ embryos were dissected free of meninges and cut into small pieces. After two $15 \mathrm{~min}$ incubations in trypsin $(1 \mathrm{mg} / \mathrm{ml}$ type III), BSA ( $5 \mathrm{mg} / \mathrm{ml}$, fraction $V$, fatty acid-free), and collagenase $10.2 \mathrm{mg} / \mathrm{ml}$, type $\mathrm{V})$, the tissue was dissociated by trituration in soybean trypsin inhibitor $(50 \mu \mathrm{g} / \mathrm{ml})$ and deoxyribonuclease $(40 \mu \mathrm{g} / \mathrm{m}$ type IV) with a Pasteur pipette, followed by passage through a 23 guage needle on a $2 \mathrm{ml}$ syringe. The cell suspension was filtered through nylon mesh, washed twice in Dulbecco's modified Eagle's medium (DMEM) containing 10\% FCS (DMEM-FCS), and plated on glass coverslips in the wells of a 24-well culture dish or in $25 \mathrm{~cm}$ culture flasks, all of which were coated with poly-D-lysine $(10 \mu \mathrm{g} / \mathrm{ml})$

Low density cultures of brain cells ( $10^{4}$ cells) died when cultured on their own. To maintain such cultures, the coverslips were grown in wells with $2 \times 10^{5}$ cells prepared at the same time. Between 2 $\times 10^{5}$ and $2.5 \times 10^{5}$ cells in $100 \mu \mathrm{l}$ of culture medium were plated in a ring around the edge of the plastic well, and $10^{4}$ cells in $10 \mu 1$ of medium were plated on a coverslip. After the cells had attached $(0.5 \mathrm{hr}), 0.5 \mathrm{ml}$ of culture medium was added to the wells; glass chips made from microscope slides were placed in the center of each well, and the coverslip bearing the $10^{4}$ cells were placed in the well on top of the chips.

E15 brain cells were initially cultured in DMEM-FCS. After I day. this was replaced with defined medium modified irom Bottenstein and Sato (1979), which contained glucose $(5.6 \mathrm{mg} / \mathrm{ml})$, bovine insu lin $(5 \mu \mathrm{g} / \mathrm{ml})$, human transferrin $(100 \mu \mathrm{g} / \mathrm{ml}), B S A(100 \mu \mathrm{g} / \mathrm{ml})$, pro gesterone $(0.06 \mathrm{ng} / \mathrm{ml})$, putrescine $(16 \mu \mathrm{g} / \mathrm{ml})$, selenium $(40 \mathrm{ng} / \mathrm{ml})$ thyroxine $(40 \mathrm{ng} / \mathrm{ml})$, and tri-todothyronine $(30 \mathrm{ng} / \mathrm{ml})$. Cultures were maintained in defined medium for over 2 months and were fed every 3 days by replacing approximately half of the medium. In some cases $0.5 \%$ FCS was added to the defined medium, particu larly for cultures grown in flasks where $3 \times 10^{16}$ to $1 \times 10^{7}$ cells were initially plated. The timing of type- 2 astrocyte development and of the production of type-2-astrocyte-inducing factor(s) wa identical with or without $0.5 \%$ FCS, but brain cells survived better in flasks containing $0.5 \%$ FCS

Newborn Brain

Cultures were prepared as described above except that the incuba tion times in trypsin and collagenase were extended to $30 \mathrm{~min}$, tis sue was triturated with a Pasteur pipette only, and cultures were grown from the start in defined medium containing $0.5 \%$ FCS and maintained in this medium for over 1 month. Neurons (identified with the monoclonal antibody RT97, which recognizes neurofilament proteins [Wood and Anderton, 1981]) were present in the cultures throughout this period.

Optic Nerve

Cultures were prepared as previously described (Miller et al., 1985) except that pieces of optic nerve were incubated in trypsin plus collagenase for $30 \mathrm{~min}$ without EDTA and then for $15 \mathrm{~min}$ with EDTA and 5000 cells in $15 \mu$ l of medium were cultured per coverslip. Type-1 Astrocytes

Cultures were prepared as previously described (Noble and Murray. 1984) except that, after shaking the cultures to remove the top laye of cells, the cultures were treated twice with cytosine arabinoside $\left(10^{-5} \mathrm{M}\right)$-once while in $10 \%$ FCS (to reduce the number of fibroblast-like cells) and again after switching the cultures to defined medium (to reduce the number of $\mathrm{O}-2 \mathrm{~A}$ progenitor cells). Cultures were grown in serum-free defined medium for at least 2 weeks be fore use. More than $98 \%$ of the cells in the resulting cultures were A2B5-, GFAPt astrocytes; the remaining cells were $\mathrm{A} 2 \mathrm{~B} 5^{-}$. GFAP fibroblast-like cells. Cells were passaged by removing them from flasks with trypsin $(0.25 \mathrm{mg} / \mathrm{mb})$ and EOTA $(0.2 \mathrm{mg} / \mathrm{ml})$.

\section{Meningeal Cells}

Meninges from newborn rat brain were dissociated in trypsin 11 $\mathrm{mg} / \mathrm{ml}$ ) and grown in DMEM-FCS. To eliminate type-1 astrocytes, the cultures were passaged 2-3 times and maintained in DMEMFCS until use

\section{Oligodendrocyte-Enriched Optic Nerve Cells}

Cultures were prepared from P7-P8 rat optic nerve as described above: $2 \times 10^{4}$ to $4 \times 10^{4}$ cells were plated on poly-D-lysine-coated coverslips in serum-free defined medium, and after 2 days, they were treated with cytosine arabinoside in $0.5 \%$ FCS for 3 days. The cells were then maintained in serum-free defined medium until use after a total of $10-14$ days in vitro, when $90 \%-95 \%$ of the cells were $\mathrm{CC}^{+}$oligodendrocytes (Raff et al., 1978); the remaining cells were $\mathrm{A}^{2} \mathrm{B5}^{-}, \mathrm{CFAP}^{+}$type-1 astrocytes and $\mathrm{A} 2 \mathrm{B5}^{-}, \mathrm{GFAP}^{-}$fibroblast-like cells.

Retina

Newborn rat retina was prepared as previously described. using 
only the peripheral half of the retina in order to reduce the number of type-1 astrocytes (Watanabe and Raff, 1988): $2 \times 10^{5}$ cells were pla:ed on poly-o-lysine-coated glass coverslips and grown in definc d medium containing $0.5 \%$ FCS for up to 3 weeks.

\section{Assay of Type-2-Astrocyte-Inducing Activity}

$\mathrm{CM}_{1}$, culture extracts, or purified CNTF was added to cultures of neirborn optic nerve ( 5000 cells) or newborn brain $\left(2 \times 10^{4}\right.$ cells) 30.45 min after the cells were plated. Between 20 and $24 \mathrm{hr}$ later. con erslips were fixed and stained with A2B5 and anti-GFAP antiborlies as described below. The number or proportion of brightly stained $A 2 B 5^{+}$process-bearing cells that expressed GFAP was deternined. Some type- 1 astrocytes were weakly stained with A2B5 and were not counted.

\section{Assay for CNTF Activity}

Cil ary ganglion neurons were prepared from $E 8$ chick embryos and cultured at a density of $1 \times 10^{3}$ to $2 \times 10^{3}$ cells per well in multivell dishes (Costar, $16 \mathrm{~mm}$ ) in $\mathrm{F} 14$ medium with $10 \%$ horse serum as previously described (Rohrer and Thoenen, 1978), except that thr culture dishes were coated with laminin (BRL, $2 \mu \mathrm{g} / 500 \mu \mathrm{l}$ per well) instead of heart-conditioned medium. The number of neu rons initially plated per well was determined by counting the neurons $2 \mathrm{hr}$ after plating. After $24 \mathrm{hr}$, the number of surviving neurons was counted.

\section{Immunofluorescence}

Brain and optic nerve cultures on coverslips were fixed in $4 \%$ paraformaldehyde at room temperature for $5 \mathrm{~min}$ and immunostained as previously described. To triple stain brain cultures, the cells were stained with monoclonal anti-GC antibody (Ranscht et al., 1982) (ascites, 1:500) followed by class-specific $G$ anti-MlgG3-Fl (1:100) and then with A2B5 monoclonal antibody (Eisenbarth et al., 1979) (ascites, 1:500) followed by $G$ anti-Mlg-Rd (1:100); after fixation with ac d-alcohol at $-20^{\circ} \mathrm{C}$ for $10 \mathrm{~min}$, cultures were stained with rabbit an:i-CFAP antiserum (Pruss, 1979) (1:100) followed by Sh anti-RIg-FI $(1: 100)$. All antibodies were diluted in MEPES-buffered MEM (MEM-HEPES) containing 10\% FCS.

Coverslips were mounted in Citifluor and examined with a Zeiss Universal fluorescence microscope using a $63 \times$ objective. Cultures we re photographed using either Ektachrome or Tri-X film rated 400 ASA.

\section{Conditioned Medium}

$\mathrm{CM}$ from brain cultures was collected at 3 day intervals, centrifuged to remove debris and dead cells, and stored at $-20^{\circ} \mathrm{C}$ until used. In some assays $\mathrm{CM}$ was used fresh because freezing was found to reduce type-2-astrocyte-inducing activity. CM from type-1 astrocytes, oligodendrocytes, retina, and meningeal cells was either collected as described for brain culture $\mathrm{CM}$ or assayed by coculturing the optic nerve assay cultures on top of the $\mathrm{CM}$-producing cells, separated by glass chips. Cultures were injured by passaging cells (using tryp. sir to remove cells from flasks) or scratched by drawing a plastic mcropipette tip twice across a culture of cells on a coverstip.

\section{Concentrated Conditioned Medium}

Prenylmethylsulfonyl fluoride $(1 \mathrm{mM})$ was added to $30-40 \mathrm{ml}$ of CM from type-1 astrocyte cultures $\left(3 \times 10^{6}\right.$ to $6 \times 10^{6}$ cells $)$ coller:ted 1 day after passaging. After centrifugation, the $C M$ was concentrated 40-fold by putting it in Spectropor dialysis tubing $(6-8 \mathrm{kd}$ cut off) and placing the tubing in polyethylene glycol $(20 \mathrm{kd}, \mathrm{BDH})$ fo $3-4$ hr at $4^{\circ} \mathrm{C}$. Concentrated $\mathrm{CM}$ was dialyzed against DMEM overnight at $4^{\circ} \mathrm{C}$, sterilized by filtering through a $0.2 \mathrm{\mu m}$ Millipore filer, and stored at $-70^{\circ} \mathrm{C}$

\section{Culfure Extracts}

Extracts of brain and injured type-1 astrocyte cultures were prepared b) homogenizing cells scraped from flasks in cold $\mathrm{Ca}^{2+}$ - and $\mathrm{Mg}^{2+}$. free phosphate buffered saline containing $1 \mathrm{mM}$ phenyimethylsulfo nyl floride. Homogenates were contrifuged for $10 \mathrm{~min}$ at $4^{\circ} \mathrm{C}$ in ar MSE Microcentaur and at $80,000 \times \mathrm{g}$ fo. $30 \mathrm{~min}$ at $4^{\circ} \mathrm{C}$ in an Airfuge (Beckman) to remove particulate material. Supernatants wise dialyzed against DMEM overnight at $4^{\circ} \mathrm{C}$. Protein concentra- tions were determined using a Bio-Rad kit with $\operatorname{lgG}$ as a standard. Extracts were stored at $-70^{\circ} \mathrm{C}$.

\section{Gel Filtration}

Concentrated $C M$ and culture extracts $(150-250 \mu \mathrm{g} / \mathrm{m} /$ total protein) were loaded in a volume of $0.1 \mathrm{ml}$ and run at $0.3 \mathrm{ml} / \mathrm{min}$ a room temperature in DMEM containing $0.5 \mathrm{mg} / \mathrm{ml} \mathrm{BSA}$ (fraction $\mathrm{V}$ fatty acid-free) on a Superose 12 column linked to an LCC-500 FPLC system (Pharmacia); $0.25 \mathrm{ml}$ fractions were collected for assay. BSA, ovalbumin, soybean trypsin inhibitor, and cytochrome $c$ were used at $2-7 \mathrm{mg} / \mathrm{ml}$ as size markers.

\section{Purification of CNIF}

CNTF was purified from adult Wistar rat sciatic nerves by a modification of the method of Manthorpe et al. (1986b) using DEAE ionexchange chromatography and preparative SDS-PACE. The purified CNTF gave a single silver-stained band when analyzed by SDS PAGE (S. M. H. et al., submitted) or isoelectric focusing (M. S., un published data).

\section{Acknowledgments}

We thank N. Mundy for advice on FPIC, A. Mudge, C. firench Constant, and R. H. Miller for helpful discussions of this work and A. Mudge for critical comments on the manuscript. L. E. L. was supported by a fellowship from the National Multiple Sclerosis Society of the United States. S. M. H. was supported by the National Fund for Research into Crippling Diseases.

Received May 26, 1988; revised June 30, 1988

\section{References}

Abney, E. R., Bartlett, P. P., and Raff, M. C. (1981). Astrocytes, ependymal cells, and oligodendrocytes develop on schedule in dissociated cell cultures of embryonic rat brain. Dev. Biol. 83 301-310

Angulo Y Gonzales, A. W. (1932). The prenatal growth of the albino rat. Anat. Rec. 52, 117-138.

Barbin, G., Manthorpe, M., and Varon, S. (1984). Purification of the chick ciliary neuronotrophic factor. I. Neurochem. 43, 1468-1478. Bignami, A., Eng, L. F., Dahl, D., and Uyeda, C. T. (1972). Localiza. tion of the glial fibrillary acidic protein in astrocytes by immunofluorescence. Brain Res. 43, 429-435.

Bottenstein. I. E., and Sato, G. H. (1979). Growth of a rat neuroblastoma cell line in serum-free supplemented medium. Proc. Natl. Acad. Sci. USA 76, 314-517.

Carnow, T. B., Manthorpe, M., Davis, G. E., and Varon, S. (1985). Localized survival of ciliary ganglion neurons identifies neuronotrophic factor bands on nitrocellulose blots. 1. Neurosci. 5, 19651971.

Davies, A. M., Bandtlow, C., Heumann. R., Korsching, S., Rohrer,

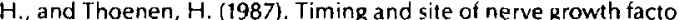
synthesis in developing skin in relation to innervation and expression of the receptor. Nature 326, 353-358.

Dubois - Dalca, M. (1987). Characterization of a slowly proliferative cell along the oligodendrocyte differentiation pathway. EMBO J. 6. $2587-2595$.

Ebendal, T. (1987). Comparative screening for ciliary neurotrophic activity in organs of the rat and chicken. I. Neurosci. Res. 17, 19-24. Eisenbarth, G. S., Walsh, F. S., and Nirenterg, M. (1979). Monoclonal antibody to a plasma membrane antigen of neurons. Proc. Natl. Acad. Sci. USA 76, 4913-4917.

ffrench-Constant, C., Miller, R. H., Burne, I. F., and Raff, M. C. (1988). Evidence that migratory oligodendrocyte-type-2 astrocyte (O-2A) progenitor cells are kept out of the rat retina by a barrier at the eye-end of the optic nerve. J. Neurocytol. 17, 13-25.

Helfand, S. L. Smith, G. A. and Wessells, N. K. (1976). Survival and development in culture of dissociated parasympathetic neurons from ciliary ganglia. Dev. Biol. 50, 541-547. 
Hughes, S. M., and Raff, M. C. (1987). An inducer protein may control the timing of fate switching in a bipotential glial progenitor cel in rat optic nerve. Development 101, 157-167.

Long, 1. A., and Burlingame, P. L. (1938). The development of the external form of the rat with observations on the origin of the extraembryonic coelom and foetal membranes. Univ. Calif. Publ. Zool. 43, 143-184.

Manthorpe, M., Rudge, J. S., and Varon, S. (1986a). Astroglial cell contributions to neuronal survival and neuritic growth. In Astrocytes, Vol. 2, S. Fedoroff and A. Vernadakis, eds. (New York: Academic Press, Inc.), pp. 315-376.

Manthorpe, M., Skaper, S. D., Williams, L. R., and Varon, S. (1986b). Purification of adult rat sciatic nerve ciliary neuronotrophic factor. Brain Res. 367, 282-286.

McMorris, F. A., Smith, T. M., DeSalvo, 5., and Furlanetto, R. W. 1986). Insulin-like growth factor $1 /$ somatomedin C: a potent in ducer of oligodendrocyte development. Proc. Nat1. Acad. Sci. USA $83,822-826$

Miller, R. H. David, 5., Patel, R., Abney, E. R., and Raff, M.C. (1985). A quantitative immunohistochemical study of macroglial cell development in the rat optic nerve: in vivo evidence for two distinct astrocyte lineages. Dev. Biol. 111, 35-41.

Nieto-Sampedro, M., Manthorpe, M., Barbin, G., Varon, S., and Cotman, C. W. (1983). Injury-induced neuronotrophic activity in adult rat brain: correlation with survival of delayed implants in the wound cavity. I. Neurosci. 3, 2219-2229.

Noble, M., and Murray, K. (1984). Purified astrocytes promote the in vitro divisions of a bipotential glial progenitor cell. EMBO J. 3. 2243-2247.

Pruss, R. (1979). Thy-1 antigen on astrocytes in long-term cultures of rat central nervous system. Nature 280, 688-690.

Rafí, M. C., Mirsky, R., Fields, K. L., Lisak, R. P., Dorfman, S. H., Sitberberg, D. H Gregson, N A Liebowitz $S$, and Kennedy, $M$ (1978). Galactocerebroside: a specific cell surface antigenic marker for oligodendrocytes in culture. Nature 274, 813-816.

Raif, M C. Abney E. R Cohen, I Lindsay $R$ and Noble $M$. (1983a). Two types of astrocytes in cultures of developing white matter: differences in morphology, surface gangliosides and growth characteristics. I. Neurosci. 3, 1289-1300.

Raff, M. C., Miller, R. H., and Noble, M. (1983b). A glial progenitor cell that develops in vitro into an astrocyte or an oligodendrocyte depending on culture medium. Nature 303, 390-396.

Raff. M. C., Abney, E. R., and Miller, R. H. (1984). Two glial cell lineages diverge prenatally in rat optic nerve. Dev. Biol. 106, 53-60.

Raff, M. C., Abney, E. R., and Fok-Seang, J. (1985). Reconstitution of a developmental clock in vitro: a critical role for astrocytes in the timing of oligodendrocyte differentiation. Cell 42, 61-69.

Raff, M. C., Lillien, L. E., Richardson, W. D., Burne, J. F., and Noble $M$. D. (1988). Platelet-derived growth factor from astrocytes drives the clock that times aligodendrocyte development in culture. $\mathrm{Na}$ ture 333, 562-565.

Ranscht, B., Clapshaw. P. A., Price, I., Noble, M., and Siefert, W. (1982). Development of oligodendrocytes and Schwann cells studied with a monoclonal antibody against galactocerebroside. Proc. Natl. Acad. Sci. USA 79, 2709-2713

Richardson, W. D., Pringle, N., Mosley, M. I. Westermark, B and Dubois-Dalcq. M. (1988). A role for platelet-derived growth factor in normal gliogenesis in the central nervous system. Cell 5.3. 309-319.

Rohrer $\mathrm{H}$, and Thoenen, $\mathrm{H}$. (1987). Relationship between differentiation and terminal mitosis: chick sensory and ciliary neurons differentiate after terminal mitosis of precursor cells, whereas sympathetic neurons continue to divide after differentiation. I. Neurosci. 7, 3739-3748.

Rudge, 1. S., Manthorpe, M., and Varon, 5. (1985). The output of neuronotrophic and neurite-promoting agents from rat brain astroglial cells: a microculture method for screening potential regulatory molecules. Dev. Brain Res. 19, 161-172.

Temple, S., and Raff. M. C. (1986). Clonal analysis of oligodendro. cyte development in culture: evidence for a development clock that counts cell divisions. Cell 44, 773-779.

Watanabe, T., and Raff, M. C. (1988). Retinal astrocytes are im migrants from the optic nerve. Nature 332, 834-837.

Williams, B. P., Abney, E. R., and Raff, M. C. (1985). Macroglial cel development in embryonic rat brain: studies using monoclonal an tibodies, fluorescence activated cell sorting and cell culture. Dev. Biol. 112, 126-134

Wood, J. D., and Anderton, B. H. (1981). Monoclonal antibodies to mammalian neurofilaments. Biosci. Rep. 1. 263-268.

\section{Note Added in Proof}

The paper referred to as S. M. H. et al., submitted, is now in pres, (Hughes, S. M., Lillien, L. E., Raff, M. C., Rohrer, H., and Sendiner, M. [1988]. Ciliary neurotrophic factor (CNTF) induces type-2 astro cyte differentiation in culture. Nature 